\title{
Præsten og selvmordet
}

\author{
Ved Mogens Lindhardt
}

\begin{abstract}
Hvordan kan præsten hjælpe i forbindelse med selvmord - når mennesker har selvmordstanker, har forsøgt selvmord eller er blevet forladt ved et selvmord? Det korte svar er: præstens hjælp består i at nedbryde menneskers entydige og færdige forestillinger om sig selv, om hinanden og om Gud. Andre hjælpere vil givet kunne dele disse ambitioner. Mit fokus her er tre forhold, som særlig præger præstens tilgang: 1) Præstens arbejde i lokalmiljøet er organiseret anderledes end andre hjælperes. 2) Præsten forventes - sikkert både af andre og af sig selv - at repræsentere en dobbelt holdning, som på en gang afviser selvmordet og som samtidig fastholder at Guds nåde også gælder for den, der tager sit liv. 3) Inddragelse af religiøst sprog og billeder, som muliggør en alternativ håndtering af $\emptyset n$ sket om at slippe væk fra sig selv og sine omgivelser.
\end{abstract}

\section{Præstens arbejde}

\section{En gang i mellem og pludselig}

Præsten, lægen, læreren eller andre rådgivere møder ikke selvmordet hyppigt og kontinuerligt, men pludselig og en gang imellem. De er ikke feltets "eksperter", og det kan være en fordel: mennesker kan komme til dem forsigtigt og prøvende, uden at skulle lægge alle tunge tanker og planer frem allerede på vej ind ad døren eller når man træffer en aftale. Men der er også ulemper for disse faggrupper: de har lettere ved at overse truende signaler eller ligefrem afvise dem. I en kritisk samtale skal modparten have tid, lang tid, til at fortælle sin historie og skal have mulighed for selv - i samtalernes $l \varnothing b$ - at formulere sine grunde til at $\mathrm{d} \varnothing$ og sine grunde til at leve. I sær det sidste er ikke noget, der ligger $\varnothing$ verst på den selvmordstuedes eller sørgendes dagsorden. Men det er nødvendigt at få frem, fordi det ligesom den langsomt udfoldede livsfortælling i sig selv kan være med til at opløse den ensidighed, hvor man glemmer at man betyder noget for nogen, at der er nogen, man gerne vil betyde noget for, og nogen som måske uønsket rammes af den $\mathrm{d} \varnothing \mathrm{d}$ og den sorg, man er ved at begrave sig i.

\section{$D$ en første uge}

Når selvmordet kommer, er det ofte præsten, der i den første uge skal hjælpe med helt basale ting: hjælpe pårørende med at få lov til at se den døde, hjælpe dem til at tale sammen og med at lægge hele begravelsesforl $\varnothing$ bet tilrette. Her afklares salmer, forl øb, stemning - skal begravelsen være i "afdødes ånd", som et hyppigt udtryk lyder - og det lægges tilrette, hvem der skal indbydes og hvordan, hvem der skal bære kisten og meget andet. De praktiske opgaver med at tilrettelægge begravelsen er i sig selv en åbning af de mere varige opgaver: hvordan vil de efterladte mestre deres tab, agte den døde, forholde sig til handlingen, til sig selv og til andre i den nye situation. Forberedelsen og gennemf $\varnothing$ rslen giver ord til chok og sorg, men udvider også sorgen til at være omsorg for hinanden og for den døde. Efterladte er i denne uge ikke kun ofre for en begivenhed, de er også ansvarlige ofre, som forholder sig handlende til deres liv og skæbne, og dermed i gang med at forvalte deres tab. Begravelsen er desuden en offentligg $\varnothing$ relse af dødsfaldet (og oftest af dødsmåden) og af de efterladte selv i en helt ny offentlig position. Den skam, der kan være ved et selvmord, fordi en familie pludselig afsløres i ikke at kunne holde på deres egen, kan både forstærkes, modvirkes og deles, når de træder frem med den d $\varnothing$ de i en kontrolleret og ritualiseret offentliggørelse. Men det er kun den første uge.

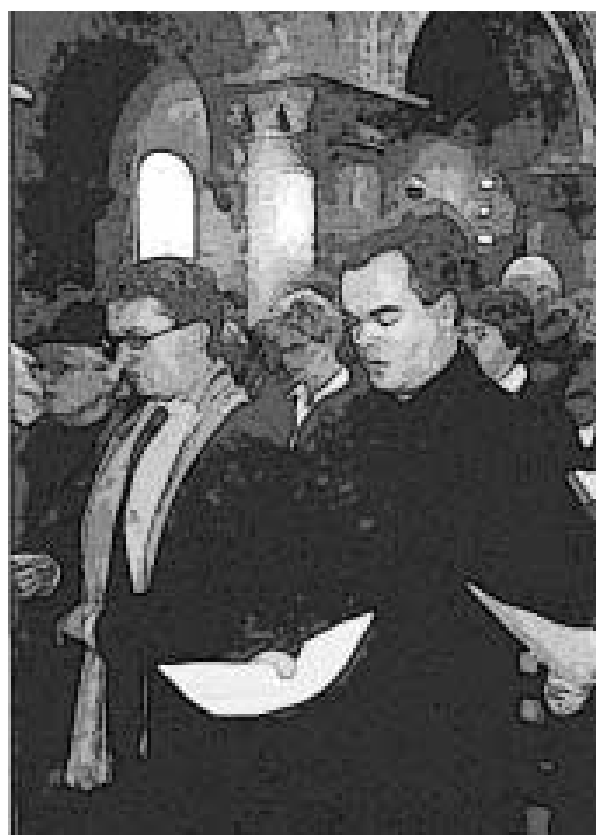

\section{Tiden efter}

Derefter er de efterladte overladte til sig selv og hinanden, dog ofte med hjælp fra professionelle, læger og psykologer. Og altså præsten, hvis arbejde ikke er bundet til et konsultationslokale med sekretær i forkontoret, ikke baseres på henvisninger eller består i betalt samtaleforl $\varnothing b$, f.eks. med offentlig st $\varnothing t t e$ over et antal gange. Præsten hører ikke på samme måde som andre til et bestemt sted, hvor man efter aftale kan gå hen og være uden for det offentlige rum. Præstens plads ligger et sted mellem eksperterne på den ene side og familie og venner på den anden. Han eller hun kan kontaktes direkte på kontoret, men der er mange andre adgangsveje: på gaden, ved indk $\varnothing b$, kirkelige møder, gudstjenester, kontakt gennem pårørende og bekendte, som kan være med til at sende signaler om behov. Netværket omkring præsten har på den måde flere åbne kanaler og hjælpen er ikke en kortvarig hjælp til at være "udenfor" sin hverdag i en periode, men snarere en kontinuerlig mulighed for at pleje sin hemmelighed med nogen i hverdagen - for efter en tid er selvmord altid en hemmelighed, noget man ikke taler med alle og enhver om, og noget "folk ved", men er forsigtige med at tale med pårørende om.

Det kontinuerlige blik fra præsten og den løbende tilgængelighed betyder, at præsten kan spilles ind i den lange periode, der følger efter den første og vigtige hjælp fra andre faggrupper og efter at venner og familie er blevet trætte af at høre om det. Præsten er der også efter et halvt år og efter to år. Og når en ung skal indskrives til konfirmandundervisning, et par skal giftes - så ved både præsten og dem, der kommer, at "det var i den familie, der skete...". Og præsten var så synligt 
tilstede ved begravelsen, at samtalen kan tages op, hvis det $\varnothing$ nskes.

\section{Præsten som livsvidne}

Præsten kan blive et livsvidne, et vidne til den skam og de sår, der har ramt mennesker. Det er måske præstens vigtigste funktion: at være en, der ved! - og om hvem både truede og efterladte ved at han eller hun ved! Præsten deler denne funktion med ganske få, måske kun med en fast praktiserende læge, som også kontaktes hyppigt om mange andre ting end følgerne af et evt. selvmord eller selv. mords $\varnothing$ nske, men som samtidig ved om selvmordet eller om selvmordstankerne. At være til rådighed, når såret åbnes eller fordi der er en tyngde, som ikke ses i det daglige og som alligevel trækker en ned, at kunne spørge og høre historien, selvom den er fortalt $f \varnothing r$, følge nuancerne skifte - det er funktionen. Den bruges ikke nødvendigvis. Det afgørende er, at den er til rådighed.

\section{Samtalen om selvmord - med truede og ofre}

Den protestantiske dobbelthed: lige for Gud og dog modparter

Forskellige hjælperes samtaler er ikke nødvendigvis særlig forskellige, hvad samtaleteknik og målsætning angår. Forskellene ligger ofte i bagtæppet, rammen omkring samtalen. Bagtæppet i præstens samtaler er den protestantiske dobbelthed, som både præger præsterne selv og de forventninger, folk kommer til dem med. To tilsyneladende modsatte synspunkter krydser hinanden: at selvmord er imod Guds vilje med livet og at den, der tager sit liv, stadig står under Guds nåde. De to synspunkter kan ikke fordeles sådan, at det ene hører til før, det andet efter en begravelse. De er begge med altid, og det præger både præsternes lutherske teologiske dannelse og i høj grad også forventningerne hos suicidale og pårørende, som de taler med. Samtalen får dermed en dobbelt dimension.

1) Præsten må fastholde, at den der vil tage sit liv, stadig står under Guds nåde og velsignelse, ligesom den, der har taget sit liv - og lige som præsten selv g $\varnothing$ r det. I forhold til velsignelse og nåde er vilkårene lige og de to samtale- parter deler de vilkår at nåden og dommen er Guds, og hverken præstens eller samtalepartnerens, og at Gud bryder igennem menneskers liv for at oprejse det faldne.

2) Samtidig må præsten fastholde, at selvmordet ikke er meningen, ikke er i orden, men en afvej. I denne dimension bliver samtalen derfor asymmetrisk og får præg af en kamp, navnlig når det handler om selvmordstruede. Præsten leder efter gode grunde til at lade være, og formodes af begge parter at være den der er tydeligst i sin holdning.

De små løsrevne sætninger med signaler, som angiver selvmordstanker, de deciderede samtaler før et selvmord og samtalerne efter, har alle karakter af forhandling om legitimiteten bag, prisen for at gøre det og anerkendelse af handlingen. Får jeg velsignelsen? Får han den? Tror du jeg får den? Har man lov til at gøre det? Var det i orden at han gjorde det? Hvad sker der, hvis man gør det? Havde han lov til at gøre det mod os? Selv det løse spørgsmål ved et selskab kan være indledning til forhandling. Spørgsmålene kommer direkte eller ligger i baggrunden, men henvendelsen til præsten har næsten altid denne spørgen om anerkendelse fra en person, som på en oftest udefineret måde repræsenterer budskabet om en anerkendelse et helt andet sted fra.

Og hver gang spørgsmålene kommer, er det opgaven, at være tro mod dobbeltheden: Nej, det er ikke i orden, at han gjorde det, og alligevel holder du af ham! Og Guds nåde kan vi ikke tage fra ham! Dobbeltheden ophæver entydigheden og muligheden for endeligt at gøre regnskabet op med sig selv eller med en anden - og det kan være redningen, både før og efter et selvmord.

\section{Du må ikke - det er forkert!}

Den teologi - ideologi - præsten mobiliserer i sin modstand mod selvmordet kan selvsagt være forskellig. Det bibelske grundlag er næsten moderne. Her omtales $i$ alt syv selvmord, og hver gang kritisk. Men kritikken gælder ikke måden at $\mathrm{d} \varnothing$ på, men det liv, der førte frem til den $\mathrm{d} \varnothing \mathrm{d}$. Selvmordet er i al kristen-jødisk kultur alvorligt og bekymrende, men ikke nød-

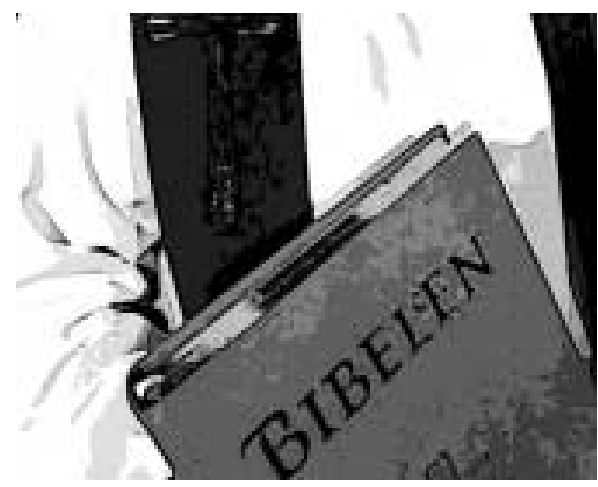

vendigvis en synd, der straffes, snarere en ulykkelig straf i sig selv - eller straf over sig selv. Men oftest st $\varnothing$ tter præster sig på mere uspecifikke bibelsteder. Det kan være en enkel fastholdelse af det sjette bud: du må ikke slå ihjel! Eller en fastholdelse af at døden er indsat af Gud selv som den afgørende forskel mellem ham og os, og at vi derfor ikke kan gøre døden til vores redskab, hverken overfor andre eller overfor os selv. Eller det kan være en fastholdelse af Gud som den nåde og kærlighed, der altid er på vej overfor vores begrænsede og tilsyneladende "færdige" forståelse af vores liv.

Selvmordet er - som mordet - ophævelse af fællesskab og kan derfor ikke afgøres etisk ud fra de rettighedsprincipper, der måtte gælde inden for et gældende fællesskab, som styrer rettigheder i forhold til hinanden.. Selvmordet rejser spørgsmålet om hvorvidt den anden vil være i fællesskabet eller ikke. Derfor hører det etisk hjemme i en afgørelses- eller kampetik, hvor begær sættes overfor begær, min krop mod den andens krop, mit ønske mod hans.

Det forhold, at præsten har teologiske og etiske grunde for at afvise selvmordet som mulighed, betyder at sygeligg $\varnothing$ relse af den truede og af de efterladte, som er trukket ned i sorg, skyld og skam, ikke er nærliggende. Præstens fordel er, at han/ hun forventes at have teologiske og etiske grunde til at være imod, og at disse grunde ikke legitimeres af den truedes eller af de kuedes tilstand, men af det, som "præsten står for". Og det som præsten står for, er noget andet end det, som den truede eller de efterladte står for, når de trækkes ned af det, der er sket. Sygeligg $\varnothing$ relse af den truede og af de efterladte, som er trukket ned i sorg, skyld og skam, er derfor ikke nærliggende. 


\section{Ingen får ret over en andens liv.}

Konsekvensen af den lutherske forståelse af nåde og velsignelse er, at ingen kan få ret over en andens liv - eller sagt på en anden måde: at hvert enkelt menneskes historie først er fortalt færdig når den er fortalt af Gud.

I forhold til den suicidale betyder det, at præsten forventes at modgå et menneskes fors $\varnothing \mathrm{g}$ på at lade andres dom og forkastelse blive til den dom, som et menneske retter mod sig selv. Lige som præsten selvsagt må modgå enhver tendens til at straffe andre med den handling, man begår mod sig selv.

I forhold til efterladte betyder det, at der er grænser for, hvor langt man skal gå i retning af at forstå, forklare, forsvare eller ford $\varnothing \mathrm{mme}$ den d $\varnothing$ des handling. Fastholdelse af det irrationelle moment i handlingen - at den i sidste ende ikke var nødvendig, men "noget, der skete", en "ulykke", en "katastrofe" eller ligefrem en "fejlhandling"- udtrykker nemlig samtidig respekt for at der er noget i en andens liv og handlinger, som et menneske hverken kan eller skal prøve at beherske, forstå eller bemestre, men må acceptere som et givet forhold man ikke har hold på. I det stykke ligner selvmordet enhver anden pludselig $\mathrm{d} \varnothing \mathrm{d}$ - det tilfældige, uforklarlige eller meningsl øse skal fastholdes.

Sporet tegnes allerede ved begravelsen. Den døde er Guds, ikke vores, vi kom ind i hans liv, som vi nu må forlade det. Og målet i begravelsen er, at den døde ikke får ret over os, ikke får lov til at fælde en endegyldig dom over vores liv. Men samtidig, at vi ikke făr ret over ham, ikke får lov til endegyldigt at kaste den vrede og fordømmelse, som er uundgåelig

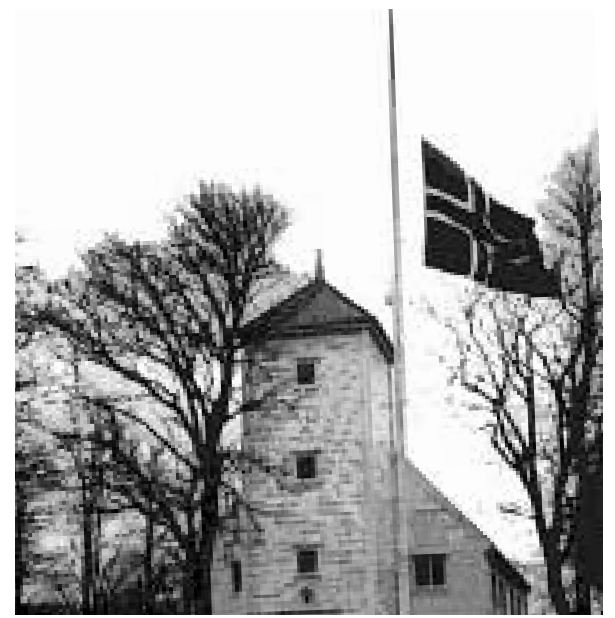

- og selvsagt skal frem, over selvmorderen, som det sidste, der skal siges om ham. Ved begravelsen lægges det spor, som følges op i alle samtaler siden hen. Vi forkynder således ikke syndernes forladelse over den døde eller over de efterladte - hver for sig. Hvorfor ikke? Fordi det, at tilgive den døde, ville være at kaste skyld på de levende eller at tilgive de levende ville være at g $\varnothing$ re den d $\varnothing$ de til entydig skadesvolder. I begravelsesgudstjenesten - som siden hen - er der kun en mulighed: at forkynde tilgivelse eller Guds nåde over både den døde og de levende, og dermed holde fast $i$, at ingen af os forvalter livet overfor hinanden, som vi gerne vil eller synes vi skulle.

\section{Sorg og selvmord}

Som hjælper ved selvmord trækker præsten sin erfaring fra andre d $\varnothing$ dsfald med sig, og kan derfor også være med til at undgå en falsk overdramatisering af selve selvmordshandlingen, som om den var det eneste ved d $\varnothing$ dsfaldet, der var opmærksomhed værd. Efterladte er ramte af selvmordet, men de er også almindeligt sørgende over at et menneske er væk.

Taknemmelighed over den afdøde, over det han gav eller det, man fik lov til at give, over at have kendt ham, refleksion over, hvad man har lært af ham eller af at leve med ham, erkendelse af det af ham, man gerne vil tage med sig, fortællinger om hans liv, tanker om, hvad man nu skal, kan og vil - alt det er almindeligt sorgarbejde. Og det er måske endnu vigtigere i forbindelse med selvmord end ellers, fordi den skam og afmagt, der knytter sig til oplevelsen af et selvmord, nemt kan få et fokus, som fortrænger det almindelige sorgarbejde og dermed også fastholder efterladte mere på den skam, som er svær at dele, end på den processuelle erfaring, som andre kan genkende og dele. Et ensidigt fokus på, at det var selvmord, kan stigmatisere de efterladte.

\section{Religiøst sprog, billeder og handlinger}

\section{G udsbilleder}

To gudsforestillinger optræder hyppigt. Den ene er forestillingen om en streng, krævende og straffende Gud, en ubønh $\varnothing r$ lig lovgiver i himmelen, som vender sig imod den, der har gjort det utilgivelige eller har misbrugt og fors $\varnothing m t$ sit liv. Det er en fjern gud, ikke til at handle med. Den anden forestilling går den modsatte vej. I forbindelse med unge pigers depression har Kristeva således og vist, forestillingen om døden som en modtagende kærlig favn, der giver den anerkendelse, vi ikke får her. Den strenge faderfigur og den kærlige modtagende Gud eller forældrefigur er begge billeder af en fjern Gud, så fjern, at han eller hun kun eksisterer som et udskammende eller kærligt blik, som ikke påvirkes af mig, og som jeg ikke har nogen kommunikation med i dette liv.

Gudsforestillinger er ikke almindelige hos suicidale. For de fleste er Gud en fuldstændig fraværende størrelse, men når de optræder - undertiden som et kirkeligt arvestykke, der ikke er til at komme af med - kan de være skadelige i deres entydighed og utilgængelighed.

Den pastoralteologiske opgave vil derfor bestå i, at bryde entydigheden og utilgængeligheden op, samtidig med at entydigheden i selvbilledet brydes op. Det sker at folk med selvmordstanker har glæde af at arbejde med bibelske tekster og billeder. Det kan være de gammeltestamentlige salmer, som ofte udtrykker vrede, sorg, frygt og kamp med den Gud de taler til, og som simpelt kan gentages i truedes og efterladtes læsning, mens der spørges til de enkelte følelsesudtryks og erfaringers genkendelighed (Capps). Men det kan også være i evangelierne, deres beskrivelser af den befrielse, kamp og modstand der er hos de mennesker, der ikke hænger sammen i deres forventninger, holdninger og erfaringer. Vigtigst er nok selve beretningen om den lidende, korsfæstede og den opstandne med d $\varnothing$ dsmærkerne i sig, fordi teksternes - og billeders - påstand om at denne lidende og mærkede er samtidig Guds s $\varnothing$ n, giver en identifikationsmulighed med det ramte, forkastede og sårede liv, som samtidig er det virkelige, bæredygtige og gavmilde liv.

Det er et krævende arbejde at forandre gudsbilleder, mange vil ikke kunne gå ind i det. Men målet med det arbejde er at komme væk fra de fjerne gudsforestillinger og søge ind mod de steder, hvor Gud og gudsforholdet er tættest muligt på den skrøbelige og udsatte kropslighed, som er genkendelig som vores liv. 


\section{Bøn}

Nogle beder, andre gør det aldrig. Men ejendommeligt nok kan man få mennesker til at bede, uanset om de ikke har gjort det siden barndommen, eller direkte siger, at Gud for dem er fuldstændig fraværende. Det er som om det at bede ikke forudsætter, at man kender den Gud man beder til. Selve det at gøre det, kan kalde en måske ukendt og ubestemt adressat frem, og give den bedende identitet og retning mod noget andet. Bønner kan være korte, måske bare et "jeg kan ikke klare mere". Bøn kan lægge sprog til klage og afmagt, men formulerer i selve udsigelsen også en mulighed for bevægelse, forandring, som er svær at formulere for sig selv eller overfor en anden i direkte form. Bønnen retter råbet mod et sted, hvor der ikke nødvendigvis skal svares, og det er måske befrielsen. Det betyder nemlig også, at der ikke stilles spørgsmål ved om det er rigtigt og ikke besvares med forsikringer og beroligelse, som nemt kan virke som underkendelse af afmagtsfølelsen.

Bønnen skaber på denne måde et rum i rummet, som er uden bedømmelse og analyse, og dermed et legitimt rum for det, som er ubærligt. I bønnen ser man samtidig væk fra den anden, der ser en, og derfor tillader bøn en vis grad af inkonsekvens hvor man ikke holdes fast på det billede af sig selv, man har fremlagt, men også kan røbe sprækker i det, sige noget mere, og til dels noget andet.

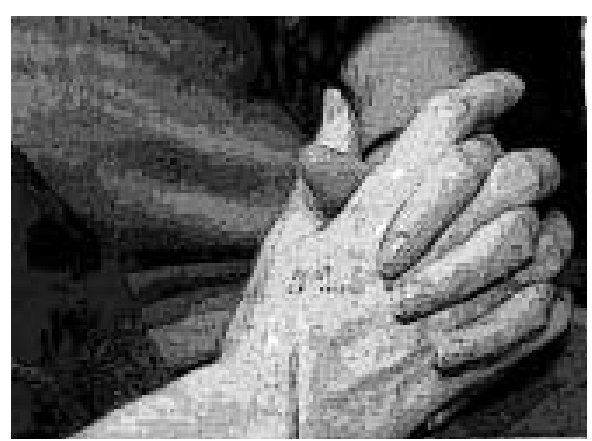

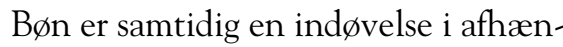
gighed og gensidighed. Den som beder, gør den han beder til, til en, der kan give - uanset om det er hinanden vi beder om noget eller om vi beder til Gud. Den røber så at sige afhængighed af en anden, samtidig med, at den trækker den anden ud af den ensomhed, det er ikke at blive bedt om noget. Den som ikke bliver bedt om noget, er en, som ikke forventes at have noget at give. Bønnen bliver derfor en træning $i$ at være $i$ afmagt og samtidig $i$ relation.

\section{Ritualer}

Jeg går med en præst ind i kirken, han læser nogle ord, giver mig brød og vin, spiser og drikker selv, lægger hånden på mit hoved, siger fadervor og lyser velsignelse og sætter sig derefter roligt ned, til jeg har lyst til at rejse mig. Hvad kommer der ud af det?

Ritualer giver sprog til følelser. Dog ikke sådan, at jeg herefter bruger ritualets sprogbrug, når jeg skal udtrykke følelser. Snarere sådan, at jeg gennem ritualet forstår, at jeg ikke forstår det, jeg ikke forstår. De giver med andre ord en anerkendt stilhed, et kortvarigt oph $\varnothing \mathrm{r}$ for tanken. Den stilhed forankres i kroppen, mere end i tanke og hoved. Ordene kan være vigtige, fordi de er genkendelige tegn, men ikke nødvendigvis vigtige i deres indhold. Det er snarere kroppen, der "tænker" og "taler" ved at bevæge sig i forhold til noget andet. Kroppen er et фjeblik ikke min modpart, som jeg fjerner fra omgivelserne i skam og vrede eller vender mig imod. I stedet indgår den $\mathrm{i}$ en rumlig scenografi, hvor der er andre, den indtager positioner, som er ubrugte i hverdagen, den er stille, tager imod, berøres. Ritualets kraft ligger i det kropslige og i at de handlinger den indgår i, og de ord der siges, ikke er mine og min tids ord, men er opstået udenfor min sociale hverdag. Derfor behøver jeg kun i begrænset omfang at "forstå" dem, selvom jeg følger dem. De er som voksensprog i den spædes barndom.

Ritualer af den type er ligesom bøn en indøvelse i kontakt, bevægelse og i at lade noget andet komme til. Man træder ud af sit daglige rum, uden at være alene, og dog udenfor samtalens kamp og uden for de aktuelle relationers magt.

Selvmordets essens er at slippe væk. Arbejde med selvmord handler derfor om at lære mennesker at slippe væk uden at de dør af det. De fleste af os har mange muligheder for at slippe væk, gøre noget andet, flytte opmærksomheden - og vi g $\varnothing \mathrm{r}$ det dagligt og ofte. De truede er dem, som kun har få muligheder tilbage - den udst $\varnothing$ dte, psykisk syge, ensomme, gamle. Og dem, for hvem én tanke er blevet så besættende, at den fylder alt - en mistet kærlighed, en $\varnothing$ delagt karriere, en stor sorg.

De spirituelle udtryksmidler, som præsten specifikt arbejder med, er en af mange muligheder for at slippe væk uden at gå til af det. De handler om skabe et rum, et sprog og en praksis for det $i$ et menneske som ikke kan integreres i den sociale verden med dens krav om nærvær, intimitet, anerkendelse og vellykkethed.

Ritualer, bønner, kristuskranse og hvad der ellers bruges, frig $\varnothing r$ kroppen og bevidstheden fra det som hører den daglige, sociale verden til og giver samtidig et sprog, hvori denne frigørelse kan udfolde sig. Det spirituelle sprog anerkender, at der er noget i mig, som ikke hører den daglige verden til, og at jeg gennem ord og handlinger kan forholde mig til det som er udenfor mig og mit sociale liv.

Det er stadig voldsomt at opleve og føle at man er sat uden for den verden man lever i - og sådan har både de truede og de efterladte det. Men det bliver måske på længere sigt nemmere at håndtere, hvis der er et sprog og en praksis, som giver en lov til at være udenfor og hvorigennem man kan forholde sig til noget andet end sig selv og sin omverden. Så man kan slippe væk - uden at blive væk.

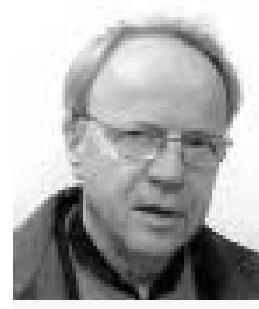

Mogens Lindhardt er rektor for Folkekirkens Institut for præsteuddannelse, København (siden 1998) og hjælpepræst ved Vor Frelsers kirke. Er tilknyttet netværket omkring Center for selvmordsforebyggelse, Odense. Har udgivet I konen med det E vige L iv, 1991 og V ielsen, 2002 og derudover artikler om religionspsykologi, ledelse, selvmord, kunst, film og medier, spiritualitet, begravelse, prædiken m.m.

\section{Litteratur}

Anneberg, I.(2002): Sorgen ved selvmord. København: Høst og Søn.

Kristeva, J. (1989): B lack sun. D epression and melancholia. Columbia University press.

Capps, D. (1993): T he depleted self. Minneapolis: Augsburg Fortress.

Morrison, A. P. (1998): T he culture of shame. London: Jason Aronson.

De Pisón, R.M. (2006): D eath by despair, shame and suicide. New York. Peter Lang. 